\title{
Evaluation of the Companies' Performance: A Study on Mobile Telecommunication Companies in Bangladesh
}

\author{
Taposh Kumar Neogy \\ Assistant Professor (Accounting), Institute of Business Administration (IBA), National University, Rajshahi, BANGLADESH \\ E-mail for correspondence: taposhknru_bd@yahoo.com \\ Cell Phone: +8801843322422 \\ Received: Aug 19, 2014; \\ Accepted: Aug 27, 2014; \\ Published: Sep 10, 2014 \\ Source of Support: Nil \\ No Conflict of Interest: Declared

\begin{abstract}
In the evaluation of the operating results of the selected mobile telecommunication companies, it is evident that the Company \# 1 could earn good profit during the study period but the performance of Company \# 2 is not satisfactory because it has been continuously facing loss for the last several years with the exception of 2011. The operating performance of Company \# 1 is better than that of Company \# 2 during the period under study. In addition, some hypotheses have developed regarding the operating results and all hypotheses are rejected which indicate that there is significant difference in operating results of the selected mobile telecommunication companies during the period under study.
\end{abstract}

Keywords: Performance Evaluation, Mobile Telecommunication Companies, Bangladesh

\section{INTRODUCTION}

Communication is an integral part of human life. From the very beginning of human civilization people tried to communicate with each other to fulfill the social needs. Over the passing of time though the tools of communication changed but still they exist in the society. Currently mobile telecommunication has brought a revolution in the field of communication. Telecommunication had made the whole world a small village and by using this service, life has become more comfortable and easy. Telecommunication sector plays a vital role in the economy of Bangladesh by creating employment opportunities, generating revenues and contributing to different types of social programmes. The telecommunication sector also plays important role by contributing to health, education, environment, sports and all other social sectors as corporate social responsibility (Zamil and Hossen, 2012). In Bangladesh, the growing rate of using mobile telecommunication is very high and it has significant effect on the socio-economic sector of the country. Mobile telecommunication exercises great power in developing countries having good impact but the lack of technology and communication makes it difficult for developing countries to participate in the global scenarios and their benefits. As one of the fastest growing sectors of the economy, mobile telecommunication companies have taken steps to promote social responsibility (Bairagi, Roy and Polin, 2011). Innovation is a widely used strategy across industries in many countries. It is now at the top of the agenda of the mobile telecommunication industry in Bangladesh. The contribution of services sector towards the economic activities is increasing gradually. Mobile telecommunication sector is one of the major contributors in terms of revenues, employments and infrastructure development (Ratan, Alam and Sohel-Uz-Zaman, 2007). Mobile telecommunication companies have emerged as an important economic sector in present time and it is adding a lot in boosting up the economy of Bangladesh. The mobile telecommunication companies in Bangladesh are aiming at providing cost effective and quality services to the customer as customer satisfaction is most important for the survival and success of any company. Mobile telecommunication has become an important tool for modern life. Our Government has granted permission to Bangladesh Telecom Private Limited to introduce the mobile telecommunication operation and other wireless communication networks for the first time in 1989 to spur private investment in this sector (Bangladesh Economic Review, 2006). Since then, mobile telecommunication companies in Bangladesh have been playing a vital role in the economic development and life style of the people. Grameenphone Ltd. is a public limited company and incorporated in Bangladesh in 1996 under the Companies Act, 1994. Grameenphone Ltd. started its various activities on 26th March, 1997 (Annual Report of GPL). Teletalk Bangladesh Limited was incorporated as a public limited company on 26th December 2004. The Company obtained the certificate of Commencement of Business from the Registrar of Joint Stock Companies and Firms on the same 
day. The Company is wholly owned by the Government of the Peoples' Republic of Bangladesh and represented by various ministries and Bangladesh Telegraph \& Telephone Board (BTTB) presently called BTCL. Teletalk Bangladesh Limited started commercial launching of operation on 31 March, 2005 (Annual Report of TBL).

\section{Objective and Methodology of the Study}

The objective of the study is to evaluate the operational results of the selected mobile telecommunication companies in Bangladesh for five years starting from 2008 to 2012. At present, six mobile telecommunication companies are working in Bangladesh in which Grameenphone Limited (here in after Company \# 1) and Teletalk Bangladesh Limited (here in after Company \# 2) have been selected for the present research study. The present study is based on secondary data and these data have been collected from the audited annual reports of the selected mobile telecommunication companies and related bodies. Researcher has used average, standard deviation, coefficient of variation and $t$ test for analyzing the collected data.

\section{HYPOTHESIS OF THE STUDY}

The present study has formulated the form of null hypotheses and these hypotheses are given below:

$\mathrm{Ho}_{1}$ : There is no significant difference in operating revenue of the selected mobile telecommunication companies.

$\mathrm{Ho}_{2}$ : There is no significant difference in gross profit of the selected mobile telecommunication companies.

$\mathrm{Ho}_{3}$ : There is no significant difference in operating profit of the selected mobile telecommunication companies.

$\mathrm{Ho}_{4}$ : There is no significant difference in profit before tax of the selected mobile telecommunication companies.

$\mathrm{Ho}_{5}$ : There is no significant difference in profit after tax of the selected mobile telecommunication companies.

\section{Findings And Testing OF THE Hypotheses}

Financial performance analysis generally means the analysis of operational results which represent the company's performance as well as the operating performance at the end of every accounting period reflected in the different financial statements. Financial performance analysis is the process of determining the operating results of selected companies from the financial statements. Financial analysis is to determine the efficiency of the company's management. Financial performance is also important to understand the financial position of selected companies. The purpose of the financial analysis is to know the efficiency and performance of company's management. In the following section researcher has analyzed the operational results of the selected companies, developed null hypotheses and conducted paired sample $t$ test to test the null hypotheses.

Table 1 shows the operating revenue of the selected companies during the period under study. The average operating revenue is 76375.74 million of Company \# 1 and 2453.14 million of Company \# 2. The standard deviation of operating revenue is 13591.00 and 828.96 respectively. The coefficient of variation of operating revenue is 17.79 and 33.79 respectively during the period under study. The Table shows that the operating revenue of Company \# 1 is greater than that of Company \# 2 during the study period. The Table also shows an increasing tendency.

Year-wise Operating Revenue- $\mathrm{Ho}_{1}$ : There is no significant difference in operating revenue of the selected companies.

Table \# 1

Table showing the operating revenue of the selected companies

\begin{tabular}{|c|c|c|c|c|}
\hline Year & Company \# 1 & Company \# 2 & $t$ & Sig. \\
\hline 2008 & 61358.98 & 1519.08 & \multirow{8}{*}{12.934} & \multirow{8}{*}{0.000} \\
\hline 2009 & 65299.57 & 1900.01 & & \\
\hline 2010 & 74724.50 & 2284.01 & & \\
\hline 2011 & 89006.70 & 2989.81 & & \\
\hline 2012 & 91488.94 & 3572.80 & & \\
\hline Avg. & 76375.74 & 2453.14 & & \\
\hline SD & 13591.00 & 828.96 & & \\
\hline $\mathrm{CV}$ & 17.79 & 33.79 & & \\
\hline
\end{tabular}

(Source: Audited Annual Reports of the Selected Companies)

In order to see whether there is any significant difference in operating revenue of the selected companies, researcher conducted paired sample $t$ test. The result shows that $t$ value is 12.934 which is significant at 0.000 level and the null hypothesis is rejected. This indicates that there is significant difference in operating revenue of the selected companies. The following Graph clearly presents the year-wise operating revenue of the selected companies during the period under study.

\section{Graph \# 1}

Graphical presentation of the operating revenue of the selected companies

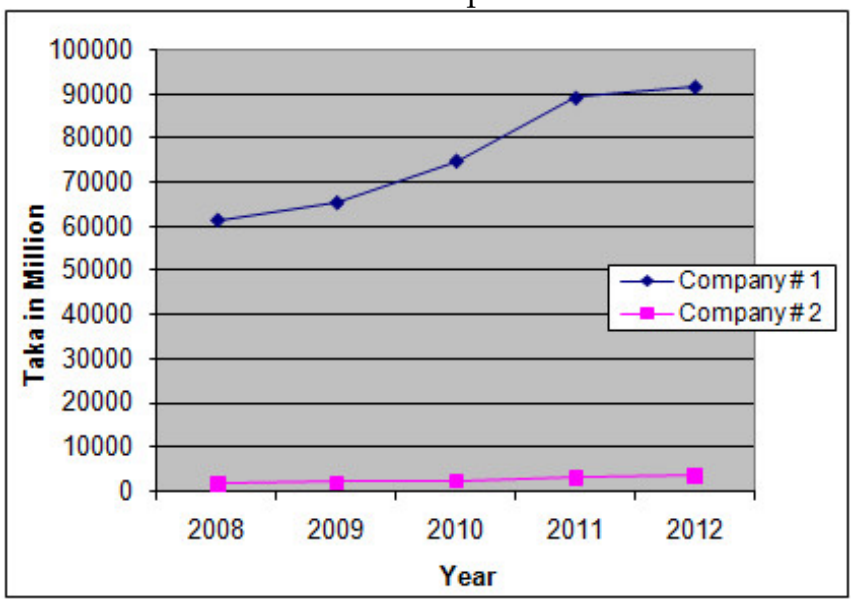

Source: Audited Annual Reports of the Selected Companies

The Graph 1 shows the year-wise operating revenue of the selected companies and the increasing tendency of operating revenue of the selected companies. The Graph presents that the selected companies earned the highest revenues in the year 2012 and the lowest in the year 2008 
during the period under study. The Graph also presents the operating revenue of the Company \# 1, greater than that of Company \# 2.

Year-wise Gross Profit- $\mathrm{Ho}_{2}$ : There is no significant difference in gross profit of the selected companies.

Table \# 2

Table showing the gross profit of the selected companies (Taka in Million )

\begin{tabular}{|c|c|c|c|c|}
\hline Year & Company \# 1 & Company \# 2 & $\mathrm{t}$ & Sig. \\
\hline 2008 & 29590.21 & 320.04 & \multirow{8}{*}{9.081} & \multirow{8}{*}{0.001} \\
\hline 2009 & 32221.67 & 898.25 & & \\
\hline 2010 & 38403.09 & 1426.02 & & \\
\hline 2011 & 50949.54 & 1886.02 & & \\
\hline 2012 & 51778.36 & 2028.22 & & \\
\hline Avg. & 40588.57 & 1311.71 & & \\
\hline SD & 10347.78 & 708.99 & & \\
\hline $\mathrm{CV}$ & 25.49 & 54.05 & & \\
\hline
\end{tabular}

(Source: Audited Annual Reports of the Selected Companies)

Table 2 shows the gross profit of the selected companies during the period under study. The average gross profit is 40588.57 million of Company \# 1 and 1311.71 million of Company \# 2. The standard deviation of gross profit is 10347.78 and 708.99 respectively. The coefficient of variation of gross profits is 25.49 and 54.05 respectively during the period under study. The gross profit of Company \# 1 and Company \# 2 show increasing tendency. In order to see whether there is any significant difference in gross profit of the selected companies paired sample $t$ test was conducted. The result shows that $t$ value is 9.081 which is significant at 0.001 level. So, the null hypothesis is rejected. This indicates that there is significant difference in gross profit of the selected companies. In fine, it can be opined that the gross profit of Company \# 1 is better than that of the Company \# 2 during the study period. The following Graph clearly presents the year-wise gross profit of the selected companies during the period under study.

\section{Graph \# 2}

Graphical presentation of the gross profit of the selected companies

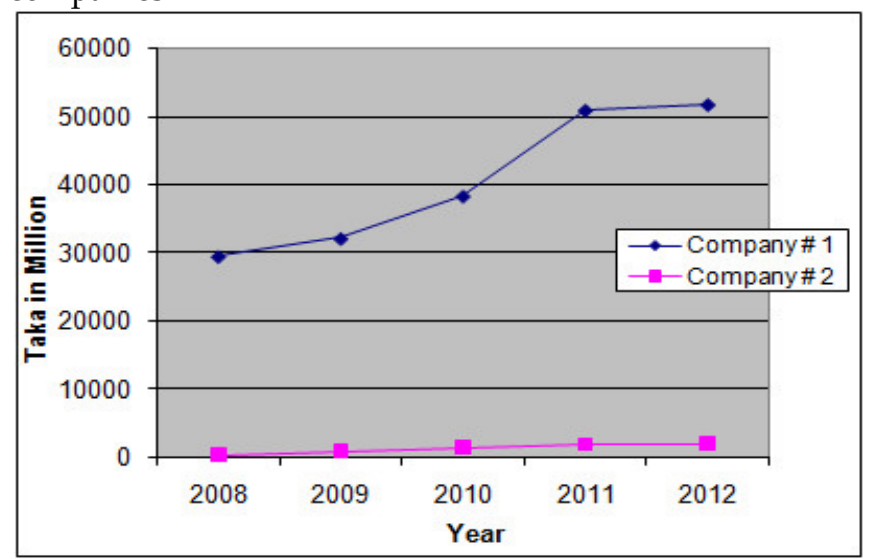

Source: Audited Annual Reports of the Selected Companies
The Graph 2 presents the year-wise gross profit of the selected companies. The Graph presents that the selected companies earned the highest gross profit in the year 2012 and lowest in the year 2008 during the period under study but the increasing trend of gross profit of 2012 of Company \# 1 was minimum. The Graph also shows that the gross profit of the Company \# 1, greater than that of Company \# 2 during the period under study.

Year-wise Operating Profit- $\mathrm{Ho}_{3}$ : There is no significant difference in operating profit of the selected companies.

Table \# 3

Table showing the operating profit of the selected companies (Taka in Million)

\begin{tabular}{|c|c|c|c|c|}
\hline Year & Company \# 1 & Company \# 2 & $t$ & Sig. \\
\hline 2008 & 15349.97 & -1246.75 & & \\
\hline 2009 & 20518.21 & -1363.77 & & \\
\hline 2010 & 20082.05 & -674.34 & & \\
\cline { 1 - 3 } 2011 & 32741.21 & 485.84 & \multirow{2}{*}{7.561} & 0.002 \\
\hline 2012 & 33474.36 & 321.72 & & \\
\cline { 1 - 3 } Avg. & 24433.16 & -495.46 & & \\
\hline SD & 8178.18 & 863.30 & & \\
\cline { 1 - 3 } CV & 33.47 & -174.24 & & \\
\hline
\end{tabular}

(Source: Audited Annual Reports of the Selected Companies)

Table 3 shows the operating profit of the selected companies during the period under study. The average operating profit of Company \# 1 and Company \# 2 is 24433.16 million and -495.46 million respectively. The standard deviation of operating profit is 8178.18 and 863.30 respectively. The coefficient of variation of operating profit is 33.47 and -174.24 respectively during the period under study.

The Table shows the operating profit of Company \# 1 increasing tendency and the operating profits of Company \# 2 negative all the years except 2011 and 2012 during the study period. So, it is evident that the operating profit of Company \# 1 is better that that of Company \# 2 during the study period. In order to see whether there is any significant difference in operating profit of the selected companies paired sample $t$ test has been conducted.

The result shows that $t$ value is 7.561 which is significant at 0.002 level. So, the null hypothesis is rejected. This indicates that there is significant difference in operating profit of the selected companies. The following Graph clearly presents the year-wise operating profit of the selected companies.

The graph 3 shows the operating profit position of selected companies covering a period of five years. The highest operating profit position was in 2012 and the lowest operating profit position was in 2008 during the period under study. 


\section{Graph \# 3}

Graphical presentation of the operating profit of the selected companies during the years 2008 to 2012

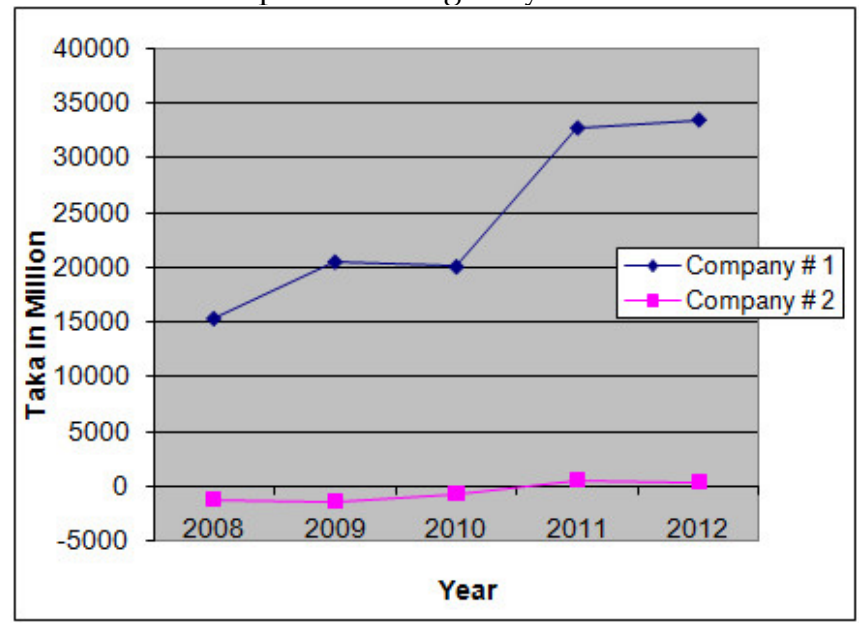

Source: Audited Annual Reports of the Selected Companies

The graph also shows that the operating profit position of Company \# 1 has increased and decreased tendency during the period under study. The operating profit of Company \# 2 is negative in the years 2008, 2009 and 2010 and positive in the years 2011 and 2012 during the period under study. In fine, it is evident that the operating profit position of Company \# 1is better than that of Company \# 2.

Year-wise Profit before Tax- $-\mathrm{Ho}_{4}$ : There is no significant difference in profit before tax of the selected companies.

Table \# 4

Table showing the profit before tax of the selected companies (Taka in Million)

\begin{tabular}{|c|c|c|c|c|}
\hline Year & Company \# 1 & Company \# 2 & t & Sig. \\
\hline 2008 & 11578.84 & -1158.59 & & \\
\cline { 1 - 3 } 2009 & 18595.96 & -1302.58 & & \\
\hline 2010 & 20785.85 & -629.84 & & \\
\cline { 1 - 3 } 2011 & 33164.94 & 468.10 & \multirow{2}{*}{0.503} & 0.003 \\
\hline 2012 & 30039.76 & 271.88 & & \\
\cline { 1 - 3 } Avg. & 22833.07 & -470.21 & & \\
\cline { 1 - 3 } SD & 8767.64 & 809.83 & & \\
\hline CV & 38.40 & -172.23 & & \\
\hline
\end{tabular}

(Source: Audited Annual Reports of the Selected Companies)

Table 4 expresses the profit before tax of the selected companies during the period under study. The average profit before tax is 22833.07 million of Company \# 1 and 470.21 million of Company \# 2 respectively. The standard deviation of profit before tax is 8767.64 and 809.83 respectively. The coefficient of variation of profit before tax is 38.40 and -172.23 respectively during the period under study. The Table shows the profit before tax of Company \# 1 increasing and decreasing tendency and the Company \# 2 negative all the years exception 2011 and 2012 during the study period. In order to see whether there is any significant difference in profit before tax of the selected companies paired sample $t$ test has been conducted.
The result shows that $t$ value is 6.503 which is significant at 0.003 level. So, the null hypothesis is rejected. This indicates that there is significant difference in profit before tax of the selected companies. The following Graph clearly presents the year-wise profit before tax of the selected companies during the period under study.

\section{Graph \# 4}

Graphical presentation of the profit before tax of the selected companies

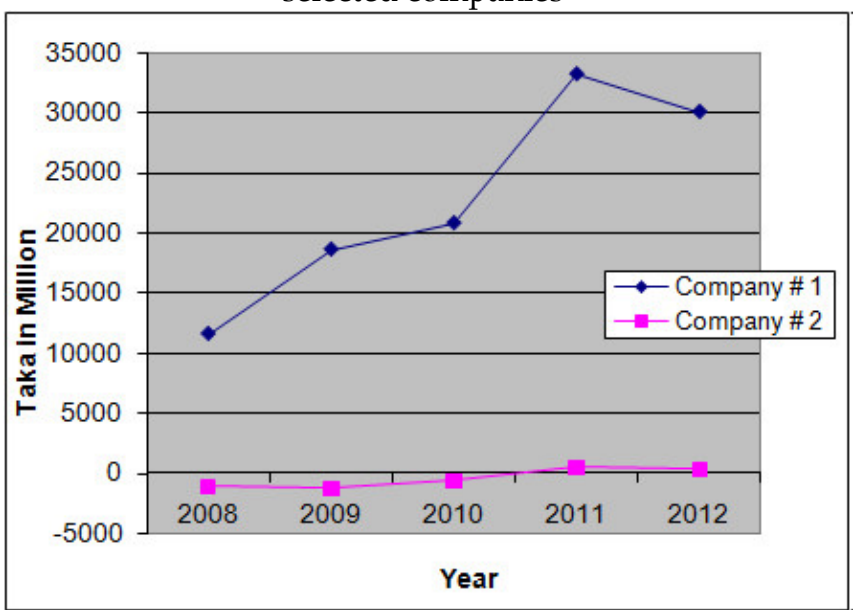

Source: Audited Annual Reports of the Selected Companies

The Graph 4 shows the profit before tax position of selected companies during the period under study. The Company \# 1 has earned the highest profit before tax in the year 2011 and the lowest in the year 2008 during the period under study. It is found that the profit before tax of Company \# 1 has increased and decreased during the period under study. The Graph also shows that the Company \# 2 has failed to earn profit before tax all the years expect year 2011 and 2012 during the period under study. In fine it is evident that the profit before tax position of Company \# 1 is greater than that of Company \# 2 during the period under study.

Year-wise Profits after Tax-Ho5: There is no significant difference in profit after tax of the selected companies.

Table \# 5

Table showing the profit after tax of the selected companies

\begin{tabular}{|c|c|c|c|c|}
\hline Year & Company \# 1 & Company \# 2 & $\mathrm{t}$ & Sig. \\
\hline 2008 & 2983.87 & -1626.53 & & \\
\hline 2009 & 14968.17 & -1099.61 & & \\
\hline 2010 & 10579.18 & -288.94 & & \\
\cline { 1 - 3 } 2011 & 19052.70 & 110.28 & \multirow{5}{*}{5.172} & 0.007 \\
\hline 2012 & 17354.54 & -175.04 & & \\
\hline Avg. & 12987.69 & -615.97 & & \\
\hline SD & 6435.32 & 721.79 & & \\
\hline CV & 49.55 & -117.18 & & \\
\hline
\end{tabular}

(Source: Audited Annual Reports of the Selected Companies)

Table 5 shows that the profit after tax of the selected companies during the period under study. The average 
profit after tax is 12987.69 million of Company \# 1 and 615.97 million of Company \# 2 respectively during the period under study. The standard deviation of profit after tax is 6435.32 and 721.79 respectively. The coefficient of variation of profit after tax is 49.55 and -117.18 respectively during the period under study. The Company \# 1 shows increasing and decreasing tendency for earning profit during the study period but the profit after tax of Company \# 2 is negative all the years expect the year 2011 during the study period. In order to see whether there is any significant in profit after tax of the selected companies paired sample $t$ test was conducted. The result shows that $t$ value is 5.172 which is significant at 0.007 level and the null hypothesis is rejected. This indicates that there is significant difference in profit after tax of the selected companies. The following Graph clearly presents the year-wise profit after tax of the selected companies during the period under study.

\section{Graph \# 5}

Graphical presentation of the profit after tax of the selected companies

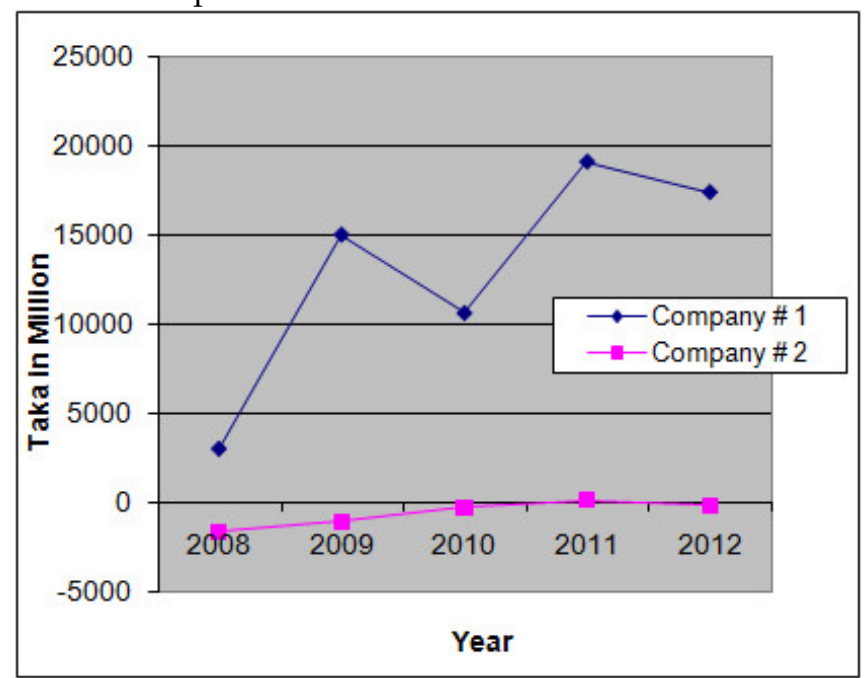

(Source: Audited Annual Reports of the Selected Companies)

The Graph 5 shows the year wise net profit of the selected companies during the study period. The Company \# 1 has earned the highest net profit in the year 2011 and lowest in the year 2008 during the period under study. The Graph presents the increasing and decreasing tendency of earnings of net profit of Company \# 1 during the period under study. The Graph also shows that the Company \# 2 is facing losses expect in the year 2011 during the period study. The Graph also presents the net profit of the Company \# 1 which is greater than that of Company \# 2 during the period under study.

\section{CONCLUSION}

This present research study evaluates the companies' performance through the analysis of the operational results. From the previous analysis it is evident that the operational results of the selected mobile telecommunication companies over the study period Company \# 1 has been able to earn good profit but the performance of Company \# 2 is not satisfactory because it had been continuously facing loss for the last several years with the exception of 2011.The financial position of Company \# 1 is better than that of Company \# 2 during the period under study. By proper accounting, management and financial control Company \# 1 has shown better performance than that of Company \# 2 in respect of earning profit. Poor internal management is responsible for making unable of earning profit and the company should take necessary steps for improving good internal management. In addition, all hypotheses are rejected which indicate that there is significant difference in operational results of the selected mobile telecommunication companies during the period under study.

\section{REFERENCES}

Ahmed AA and Ahmad M. 2009. An Empirical Analysis of Performance Measurement of the Disclosure in Financial Reporting: A Study of Banking Sector in Bangladesh COMSATS Institute if Information Technology 2nd COMSATS International Business Research Conference. Lahore, Pakistan: CIIT.

Ahmed AA, Khan W and Hossain MS. 2011. Reporting Practice of Accounting Disclosure on Changes in Listed Companies of Bangladesh ASA University Review, 5, 83-96.

Ahmed AA. 2012. Disclosure of Financial Reporting and Firm Structure as a Determinant: A Study on the Listed Companies of DSE ASA University Review, 6, 44-60.

Ahmed, A., \& Siddique, M. (2013). Internet Banking Espousal in Bangladesh: A Probing Study. Engineering International, 1(2), 40-47. Retrieved from http://journals.abc.us.org/index.php/ei/article/view/2.4 $\% 281 \% 29$

Annual Reports of Grameenphone Limited and Teletalk Bangladesh Limited from the years 2008 to 2012

Bairagi, A. K., Roy, T. and Polin, A. (2011),"Socio-Economic Impacts of Mobile Phone in Rural Bangladesh: A Case Study in Batiaghata Thana, Khulna District", IJCIT, Vol. 02, Issue 1, pp. 42-48.

Bangladesh Economic Review, (2009) Economic Adviser's Wing, Finance Division, Ministry of Finance, Government of the People's Republic of Bangladesh, June

Block and Hirt (2000), "Foundation of Financial Management", 9th Edition, Irwin McGraw- Hill, Boston, USA

Gujarati, Damodar N. (1998), "Basic Econometrics", (3rd Ed.) McGraw - Hill International Editions, Economic Series, Singapore

Hossain, et. al, (2008), “Financial Performance of GrameenPhone Ltd.: An Overview", Islamic University Studies (Part c), Volume 7, No. 2, June

Khan, M.Y. and Jain, P.K. (2002), "Financial Management", Prentice Hall of India New Delhi

Neogy, T. (2014). Evaluation of Efficiency of Accounting Information Systems: A Study on Mobile Telecommunication Companies in Bangladesh. Global Disclosure Of Economics And Business, 3(1), 40-55. Retrieved from http://ischolar.in/index.php/GDEABC/article/view/54529 
Pandey, I. M., (2007), "Financial Management", Vikas Publishing House Pvt. Ltd., Delhi

Ratan, S. R. A., Alam, M. S. and Sohel-Uz-Zaman, A. S. M. (2007), "Innovation Strategy: A Realistic Example in Bangladesh Mobile Telecommunication Service Marketing", The Cost and Management, Vol. 35, No. 1, January-February, pp. 49-58.

Rouf, M., Hasan, M., \& Ahmed, A. (2014). Financial Reporting Practices in the Textile Manufacturing Sectors of Bangladesh. ABC Journal Of Advanced Research, 3(2), 57-67. Retrieved from

http://journals.abc.us.org/index.php/abcjar/article/view/6.6
Siddique, M., Neogy, T., \& Islam, M. (2014). Variations in Opinions toward Disclosure Trend of Insurance Companies in Bangladesh: An Empirical Study. American Journal Of Trade And Policy, 1(1), 42-50. Retrieved fromhttp://journals.abc.us.org/index.php/ajtp/article/vie $\mathrm{w} / 1.5$

Zamil and Hossen (2012), "Problems and Prospects of Telecommunication Sector of Bangladesh: A Critical Review", New Media and Mass Communication, vol. 4, pp. 16-25.

$$
-0-
$$

